\title{
Genetic architecture of novel ornamental traits and the establishment of sexual dimorphism: insights from domestic birds
}

\author{
Ken Kraaijeveld ${ }^{1}$ (D)
}

Received: 30 November 2018 / Revised: 19 February 2019 / Accepted: 20 February 2019 / Published online: 12 March 2019

(c) The Author(s) 2019

\begin{abstract}
The evolution of sexually monomorphic ornamental traits is poorly understood and may require a shift in research focus away from strict sexual selection. To properly understand how selection affects such traits, we need to know to what extent they are constrained by their genetic architecture. Specifically, we need to understand how and in what state (monomorphic or dimorphic) ornamental traits first appear, how they are subsequently rendered sexually dimorphic, or not, and what mechanisms underlie their further elaboration and diversification. Here, I argue that recent developments in the genomic studies of domesticated birds provide insights into these questions. The causal mutations of several ornamental traits have been identified, particularly in chickens. I briefly review this literature and show that ornamental traits can be caused by a range of different types of mutations, including single-nucleotide polymorphisms and larger structural variations. Novel ornamental traits tend to be sexually monomorphic, suggesting that most cases of sexual dimorphism are the result of additional mutations, although we have no direct evidence for this in domestic birds. Several examples show how existing ornaments can be further elaborated and diversified by additional mutations. Ongoing research may also clarify what mutations cause the reversal to sexual monomorphism dull plumage in chickens. I conclude that current cases of sexually monomorphic ornamentation may consist of a mix of traits that are under selection for monomorphism and traits that are constrained to be monomorphic.
\end{abstract}

Keywords Mutual ornamentation $\cdot$ Sexual monomorphism $\cdot$ Sexual selection $\cdot$ Genetic constraint $\cdot$ Chicken

\section{Zusammenfassung}

Die Evolution sexualmonorpher Ornamente ist bisher nur unzureichend verstanden. Es bedarf daher weiterer Erklärungsversuche, vor allem solcher, die nicht auf sexueller Selektion basieren. Um zu verstehen wie Selektion auf die Ausbildung sexualmonomorpher Ornamente wirkt, muss zunächst verstanden werden, in welchem Ausmaß sie durch ihre zu Grunde liegende genetische Architektur festgelegt sind. Insbesondere muss verstanden werden wie und in welchem Zustand (monomorph oder dimorph) Ornamente zunächst auftreten, ob und wie sie anschließend als sexualdimorph festgelegt werden und welche Mechanismen ihrer weitergehenden Ausschmückung und Diversifizierung zu Grunde liegen. Ich argumentiere an dieser Stelle, dass jüngste Entwicklungen im Bereich der Genomforschung domestizierter Vögel neue Einsichten in Bezug auf die genannten Fragestellungen eröffnen. Die der Ausbildung von Ornamenten zu Grunde liegenden Mutationen sind bereits bekannt, insbesondere in Hühnervögeln. Ich gebe hierzu eine kurze Literaturübersicht und zeige, dass die Ausbildung von Ornamenten durch verschiedene Typen von Mutationen verursacht werden kann, unter anderem durch Punktmutationen aber auch durch größere strukturelle Variationen. Neu auftretende Ornamente sind im Allgemeinen monomorph, was nahe legt, dass sexualdimorphe Ornamente ein Resultat zusätzlicher Mutationen sind. Letzteres ist jedoch bei domestizierten Vögeln bisher unbelegt. Es gibt jedoch eine Reihe von Beispielen, die zeigen wie bereits existierende Ornamente durch zusätzliche Mutationen ausgeschmückt und diversifiziert werden können. Aktuelle Forschung könnte zusätzlich klären,

Communicated by F. Bairlein.

This article is a contribution to the Topical Collection 27th

International Ornithological Congress, Vancouver, Canada, 19 to 26

August 2018.

Extended author information available on the last page of the article 
welche Mutationen eine Umkehr zu sexualmonomorphem mattem Gefieder in Hühnervögeln bedingen. Abschließend folgere ich, dass gegenwärtige Fälle von sexualmonomorpher Ornamentation aus seiner Mischung von Merkmalen bestehen: Solchen, die einer Selektion auf Monomorphismus unterliegen, und solchen, bei denen Monomorphismus (bereits/genetisch?) festgelegt ist.

\section{Introduction}

Birds display a staggering diversity of traits that appear to serve no purpose in survival, such as bright plumage, elongated tail and Crest feathers, elaborate song and exuberant visual displays. Such ornamental traits are sometimes most strongly expressed by the male. A large body of research has been devoted to the study of such sexually dimorphic ornaments, particularly in birds (Andersson 1994). The conclusion emerging from this work is that sexual selection is the dominant force shaping sexually dimorphic ornaments. However, in many other species, both sexes display the ornamental trait, resulting in sexually monomorphic ornamentation (Amundsen 2000; Kraaijeveld et al. 2007; Clutton-Brock 2009). Sexually monomorphic ornaments have received far less attention and may require a shift in focus away from strictly sexual selection towards selection resulting from a much broader range of social interactions (West-Eberhard 1979; Kraaijeveld et al. 2007; Lyon and Montgomerie 2012; Tobias et al. 2012).

Implicit in this discussion is the assumption that ornaments are free to evolve between sexually monomorphic and dimorphic states. To what extent this is the case may vary between ornaments and depend on the genetic architecture underlying ornament development (Kraaijeveld 2014). Lande (1980) outlined the expected scenario for the evolution of sexually dimorphic ornamental traits; Lande's model assumed that novel traits are caused by autosomal genetic variants and appear as sexually monomorphic traits. As most of the genome is shared between the sexes, most novel
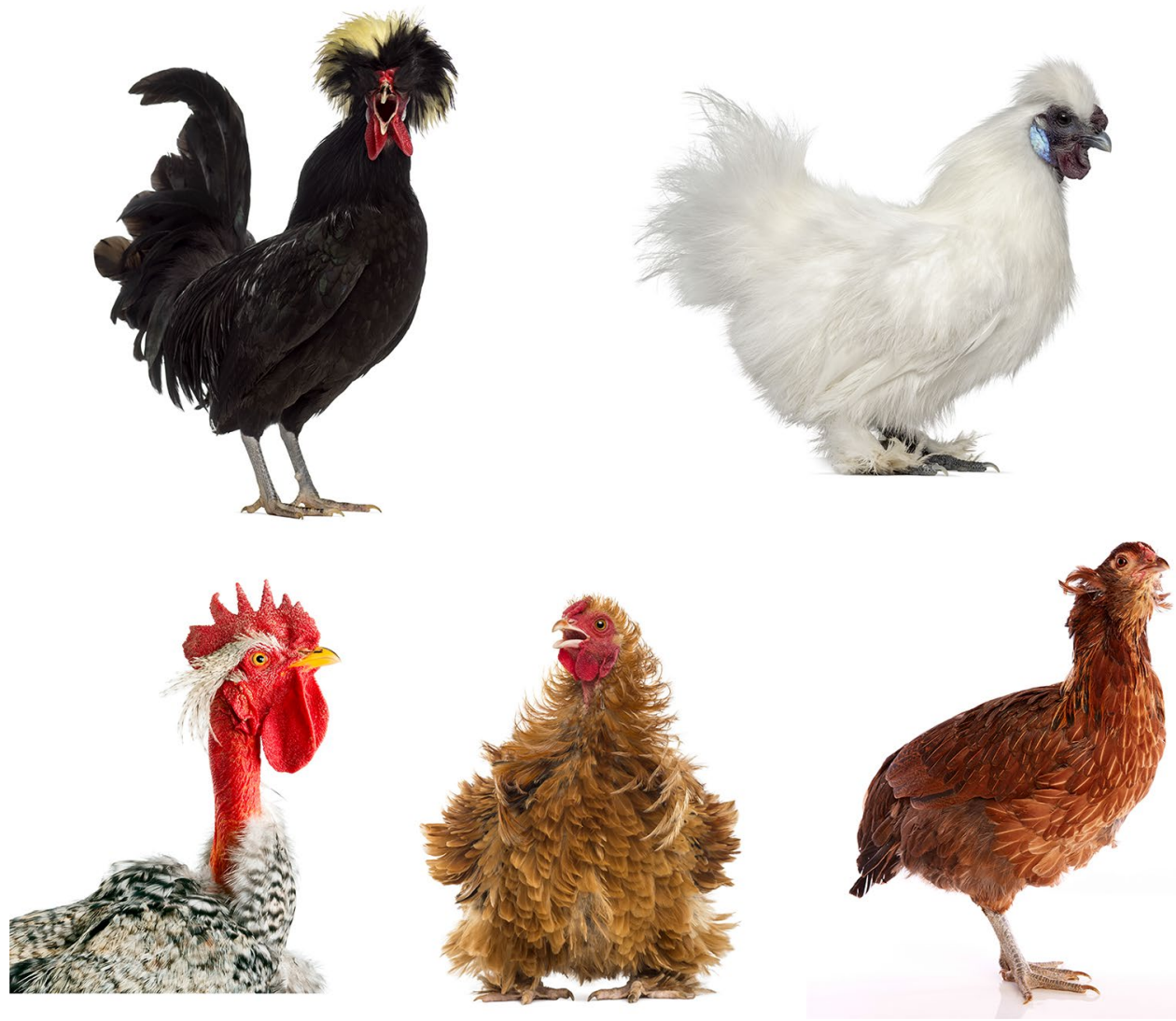

Fig. 1 Examples of chicken phenotypes that would be considered 'ornamental' if they occurred in wild birds, and for which the causal genetic mutations have been identified (see Table 1). Clockwise from top left: Crest, Silky feather, Araucana (Ear tufted), Frizzle feather, Naked neck. Images: Shutterstock 


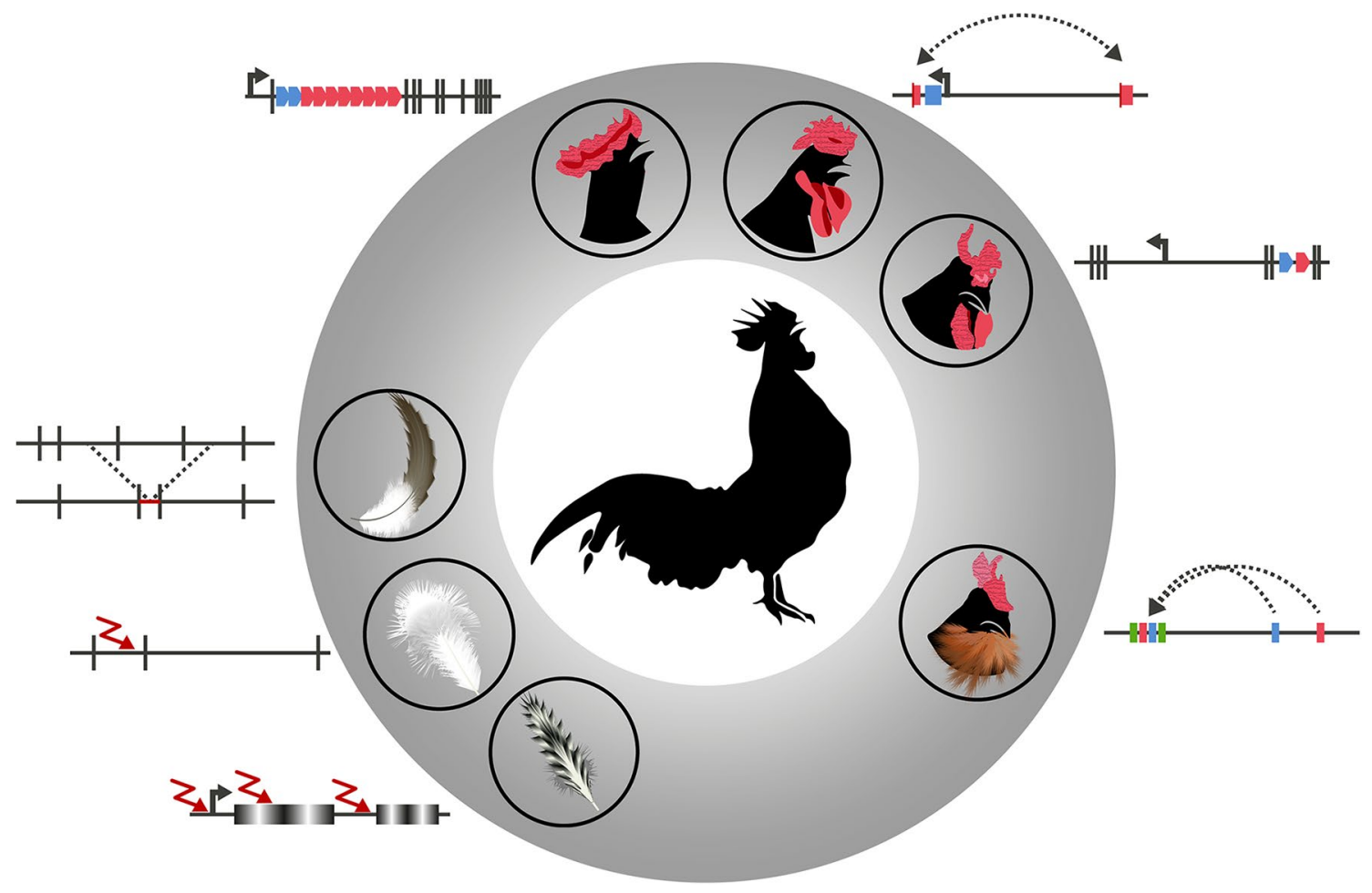

Fig. 2 Examples illustrating the diversity of genetic mutations (outer ring) causing ornamental phenotypes in chickens (inner ring). Clockwise from top: repeat expansion causing Pea comb, inversion causing Rose comb, tandem duplication causing Duplex comb, complex

ornamental traits are expected to be expressed in both males and females. Such traits are then subject to sexual or social selection through mate choice and intraspecific competition, as well as natural selection against their maintenance. These sources of selection often differ in magnitude between the sexes, resulting in sexually antagonistic selection on the ornament. When new mutations subsequently modulate the expression of the ornament such that it is only expressed in the sex that benefits from it for example by changing the sensitivity to hormones, sexual dimorphism ensues.

While this scenario makes intuitive sense, the predicted sequence of events is rarely borne out when sex-specific ornament expression is mapped onto phylogenies of closely related species (Wiens 2001; Price and Eaton 2014). There may be two reasons for this discrepancy. First, Lande's model may be incorrect and ornaments frequently arise in the sexually dimorphic state or evolve unencumbered by intersexual genetic correlation. Alternatively, the phylogenies may not be explained by Lande's model. If the ancestor of the taxonomic group under study already expressed the ornament, then the subsequent events, although interesting in their own right, are not informative with regard to Lande's model. In other words, the first appearance of sexual dimorphism and its subsequent loss and reappearance are governed by different processes. structural variation, including translocations, causing Muffs and beard, single-nucleotide mutations causing Sex-linked barring, single-nucleotide mutation causing Silky, and deletion causing Frizzled. Image: Shraddha Shitut

To gain insight into the first stages of ornament evolution, we need to observe the appearance of new ornamental traits. Domesticated birds offer excellent opportunities for such an endeavour. Many novel traits have appeared in domestic birds, including chickens, pigeons, ducks and Budgerigars, and were favoured by breeders (Price 2002). Many of these traits would qualify as 'ornamental' when observed in wild birds (Fig. 1). Indeed, several novel traits in domestic birds closely resemble ornamental traits observed in wild birds e.g. Naked neck, Frizzle feather and Ear tuft phenotypes in domestic chickens function as display traits in Turkey Meleagris gallopavo (Buchholz 1997), Black Swan Cygnus atratus (Kraaijeveld et al. 2004) and eared pheasants Crossoptilon spp. (Lu 2007), respectively. In recent years, the molecular mechanisms underlying many of these traits have been clarified in both chickens and pigeons (Fig. 2; reviewed in Boer et al. 2017). I propose that these mechanisms may parallel those that underlie similar traits in wild birds. If so, these mechanisms may provide insights into the evolution of ornamental traits and sexual dimorphism. In this paper, I review the literature on the molecular genetics of ornamental traits in domestic birds and assess what it might teach us about evolution of ornaments and sexual dimorphism in the wild. 
Table 1 Novel ornamental traits in domestic birds for which the causal genetic mutations have been identified

\begin{tabular}{|c|c|c|c|c|c|c|}
\hline Phenotype & Associated gene & Mutation type & Mutation impact & Genetics & Sexual dimorphism & References \\
\hline \multicolumn{7}{|l|}{ Chicken } \\
\hline Muffs and beard & HOXB8 & Complex SV & Cis-regulation & $\begin{array}{l}\text { Autosomal incom- } \\
\text { plete dominant }\end{array}$ & Monomorphic & Guo et al. (2016) \\
\hline Sex-linked barring & $C D K N 2 A$ & SNPs & $\begin{array}{l}\text { Two non-coding, } \\
\text { two coding }\end{array}$ & $\begin{array}{l}\text { Sex-linked domi- } \\
\text { nant }\end{array}$ & Dimorphic & $\begin{array}{l}\text { Schwochow } \\
\text { Thalmann et al. } \\
\text { (2017) }\end{array}$ \\
\hline Silky & PDSS2 & SNP & Cis-regulation & $\begin{array}{l}\text { Autosomal reces- } \\
\text { sive }\end{array}$ & Monomorphic & Feng et al. (2014) \\
\hline Ear tuft & $T B X 1$ & $?$ & $?$ & $\begin{array}{l}\text { Autosomal domi- } \\
\text { nant }\end{array}$ & Monomorphic & Noorai et al. (2012) \\
\hline Frizzle & KRT75 & $\begin{array}{l}\text { 69-Bp inframe } \\
\text { deletion }\end{array}$ & $\begin{array}{l}\text { Coding; alternative } \\
\text { splice }\end{array}$ & $\begin{array}{l}\text { Autosomal incom- } \\
\text { plete dominant }\end{array}$ & Monomorphic & Ng et al. (2012) \\
\hline Crest & HOXC8 & $?$ & Cis-regulation & $\begin{array}{l}\text { Autosomal incom- } \\
\text { plete dominant }\end{array}$ & Dimorphic & Wang et al. (2012) \\
\hline Naked neck & BMP12 & Large insertion & Cis-regulation & $\begin{array}{l}\text { Autosomal incom- } \\
\text { plete dominant }\end{array}$ & Monomorphic & Mou et al. (2011) \\
\hline \multicolumn{7}{|l|}{ Pigeon and dove } \\
\hline Crest & $E p h B 2$ & SNP & Coding & Recessive & Monomorphic & $\begin{array}{l}\text { Shapiro et al. } \\
(2013) \text { and Vick- } \\
\text { rey et al. (2015) }\end{array}$ \\
\hline
\end{tabular}

$S V$ Structural variant, $S N P$ single-nucleotide polymorphism, $B p$ base pair

\section{Most novel ornaments are rarely sexually dimorphic}

The data from domesticated birds support the assumption of Lande's model that novel traits are caused by autosomal genetic variants and appear as sexually monomorphic traits. Price (2002) reviewed the genetics of ornamental traits in ten species of domestic birds and found that $80 \%$ show autosomal inheritance. The $20 \%$ of traits with Sex-linked inheritance may be biased upward because these traits are immediately available for artificial selection, even when recessive (Price 2002). Because of female heterogameity in birds, these traits show female-biased expression when recessive. Sex-linked inheritance of recessive traits is therefore not a likely cause of sexual dimorphism of novel ornaments in birds, as sexually dimorphic ornaments in wild birds are overwhelmingly male biased.

Sex-linked inheritance of dominant traits may provide an avenue for the evolution of sexually dimorphic ornaments in birds. Because of incomplete dosage compensation for sex-linked genes in birds, dominant sex-linked traits show male-biased expression. This is exemplified by Sex-linked barring, the only sex-linked ornamental trait for which the causal mutation has been identified (Table 1). This phenotype is caused by two non-coding single-nucleotide mutations and is further attenuated by two coding mutations (Schwochow Thalmann et al. 2017). These mutations are located on the $\mathrm{Z}$ chromosome, within the regulatory regions of the gene $C D K N 2 A$ (Schwochow Thalmann et al. 2017).
The causal alleles are dominant and cause barring phenotypes in hemizygous females and heterozygous males. Homozygous males show very little pigmentation due to incomplete dosage compensation (Schwochow Thalmann et al. 2017). Expression is thus strongest in homozygous males, although in this particular case the most attractive phenotype is produced by lower expression in heterozygous males and hemizygous females.

Sex-linked inheritance is not necessarily adaptive. It is possible that a trait appears as sex biased because the causal mutations are located on the sex chromosomes when selection would actually favour sexual monomorphism. The suggestion that sexually dimorphic expression could be a maladaptive effect of the genetic makeup of the trait has, to my knowledge, not been explored.

In addition to Sex-linked barring, one other novel trait in chickens (Crest) is slightly sexually dimorphic. In this case, males show a more voluminous crest than females (Wang et al. 2012). The phenotype shows autosomal inheritance and the causal mutation appears to be located on one of the microchromosomes (Wang et al. 2012). The mutation causes ectopic expression of $\mathrm{HOXC8}$ in cranial skin (Wang et al. 2012). HOXC8 is natively expressed in the dorsal dermis during embryonic development (Kanzler et al. 1997), where it may be involved in specifying the upper tail coverts, the shape of which is sexually dimorphic. Ectopic expression of $\mathrm{HOXC} 8$ may therefore reprogram the cranial dermis to resemble the-sexually dimorphic_-dorsal dermis (Wang et al. 2012). Male-biased sexual dimorphism of the Crest 
phenotype thus seems the result of a mutation affecting a pathway that is already sexually dimorphic. In that sense, it is similar to various mutations affecting male-biased comb phenotypes in chickens (see below).

The majority of novel traits tend to appear in sexually monomorphic state (Table 1; Price 2002) and it follows that sexual dimorphism may take time to evolve. Some cases of sexually monomorphic ornamentation in nature may therefore be explained by the absence of selectable mutations that render the trait dimorphic. Alternatively, if selection does not favour sexual dimorphism, the genetic correlation will be maintained.

\section{Establishment of sexual dimorphism}

None of the novel ornaments that have appeared in domestic birds have subsequently evolved sexual dimorphism. These traits therefore provide no further insight into the early stages of the evolution of sexual dimorphism from monomorphic ancestors. However, the molecular mechanisms of sexual dimorphism of existing dimorphic ornaments have been resolved in numerous cases (reviewed in Pennell and Morrow 2013). Several mechanisms, including the action of hormones, alternative splicing, translocation of key genes to a sex chromosome and genomic imprinting have been implicated in sexual dimorphism (Pennell and Morrow 2013). For example, high constitutive levels of circulating estradiol in transgenic male chickens feminized their combs, wattles and plumage, demonstrating hormonal dependency of ornament development (Lambeth et al. 2016). Remarkably, sexual dimorphism in weight, spurs or gonads was not feminized in these transgenic males (Lambeth et al. 2016).

It would therefore seem that all that needs to evolve to render a novel ornament sexually dimorphic is a link between one of the key developmental genes and any one of these sexual dimorphism-inducing mechanisms. Whether such a route towards sexual dimorphism is open to any given trait will depend on the genetic architecture of the trait. Some traits may be easier to modulate than others. For example, there is some evidence to suggest that bird crests tend to be sexually monomorphic even when the rest of the plumage is dimorphic (Kraaijeveld 2014). It seems reasonable to expect the crest to also be subject to selection for sexual dimorphism and the absence of a response to be due to a paucity of selectable variation. Recent studies have identified the causal mutations of novel crests in pigeons and doves, which are sexually monomorphic (Shapiro et al. 2013; Vickrey et al. 2015). If similar mutations are the cause of crest ornaments in wild birds, these studies may represent advances in explaining the lack of sexual dimorphism of these traits. The gene in which these causal mutations appear, $E p h B 2$, is under the influence of androgens in mice
(Lorenzo et al. 2003), suggesting that similar hormonal modification might be possible in birds. Why this does not appear to evolve readily requires further study.

\section{Further elaboration and diversification of novel ornaments}

Once a novel ornament has appeared, selection may favour further elaboration. In nature this would normally involve various forms of social selection (including sexual selection), but artificial selection in domestic birds closely mimics this process. For example, Schwochow Thalmann et al. (2017) suggested that the different mutations involved in the Sex-linked barring phenotype arose in sequence, whereby the first mutation produced a highly diluted phenotype and breeders subsequently favoured additional mutations that produced a more appealing phenotype.

Novel ornaments may be modified in different ways, potentially providing the basis for divergent phenotypes to be selected. Breeders have applied such divergent selection by favouring and maintaining different novel forms of existing ornaments. This has been particularly well studied in chicken combs. The genetic mutations causing several different comb phenotypes have been resolved (reviewed in Headon 2015). For example, multiple variations of the Duplex comb phenotype exist in chickens. These breeds all share a 20-kilobase tandem duplication that causes ectopic expression of the gene EOMES in the ectoderm of the comb-developing region, leading to a double or split comb (Dorshorst et al. 2015). Further mutations must distinguish between the distinct Duplex comb phenotypes, known as Buttercup and V-shaped, but these have not yet been identified (Dorshorst et al. 2015). These and other mutations have caused a wide variety of comb phenotypes in chickens. Each of the novel comb phenotypes are caused by structural mutations that modulate the expression of different transcription factors (Headon 2015). It is noteworthy that none of these mutations affect the degree of sexual dimorphism: the ancestral sexual dimorphism is maintained in all the mutants (see for example Fig. 1 in Wright et al. 2009).

In the same category of mutations that cause elaboration or diversification of existing ornamental traits that may or may not have already evolved sexual dimorphism, we find mutations affecting plumage colour in a range of bird species. Price (2002) suggested that plumage colour is one of the traits in which new mutants that appeal to breeders occur most frequently. However, most mutations reduce plumage brightness, rather than enhance it. Several mutations causing plumage colour differences have been identified in for example Budgerigars (Cooke et al. 2017) and pigeons (Guernsey et al. 2013). Again, in none of these cases do the mutations affect the degree of sexual dimorphism of the trait. 


\section{Reversal to sexual monomorphism}

Phylogenetic studies have shown that once sexual dimorphism has evolved for a given ornament, it can be lost and regained easily (Wiens 2001; Price and Eaton 2014). While not studied directly in domestic birds, the loss of dimorphism in the direction of increased female ornamentation is straightforward. Sexual dimorphism in several bird ornaments, most notably in plumage colour, is achieved through hormonal suppression of ornament development (Kimball and Ligon 1999). In such cases, all that is needed for female ornamentation to reappear is altered hormone levels or sensitivity. Ovariectomy leads to the development of male-like plumage in female birds (Owens and Short 1995). Similarly, females that start developing male-like plumage later in life, when hormone levels presumably change, are observed with some regularity (Owens and Short 1995).

The reverse does not happen: castration does not result in female-like plumage in male birds (Owens and Short 1995). Instead, the production of female-like plumage in males (i.e. a change to monomorphic dull plumage) appears to require an increase in oestrogen levels. An interesting case in point is the Henny feathers phenotype in chickens. This phenotype is caused by an autosomal dominant mutation that causes males to express female-like plumage (Matsumine et al. 1991). While the precise mutation has not yet been identified, it is known that males carrying this phenotype express an alternatively spliced variant of aromatase messenger RNA as a result of the activity of a promoter element contained in an endogenous retrovirus located upstream of the aromatase gene (Matsumine et al. 1991). Aromatase is an enzyme that converts androgens to oestrogen. Ectopic expression of aromatase leads to oestrogen production in the skin, where it is normally not found in males (Matsumine et al. 1991). Aromatase expression in these birds is sensitive to 5-azacytidine treatment (Leshin 1985), suggesting a role for DNA methylation.

The hormonal basis of sexual dimorphism of ornamental traits in birds implies that selection of hormone levels or associated (behavioural) traits could lead to increased or decreased levels of dimorphism as a pleiotropic effect (Kraaijeveld and Reumer 2008). While there are currently no known examples of this in (domestic) birds, this possibility further cautions against assuming adaptive explanations for (the lack of) sexual dimorphism.

\section{Discussion}

Most novel ornaments in domestic birds appear as sexually monomorphic traits as a result of mutations that affect the expression of key developmental genes. Whether similar mutations underlie the striking ornaments in wild bird species remains to be seen. Several of the mutations uncovered in domestic birds reduce fitness, sometimes severely. The Silky feather phenotype is flightless and has poor thermoregulation (Feng et al. 2014), homozygosity for the Ear tuft mutation is lethal (Noorai et al. 2012) and the original mutation that causes the Rose comb phenotype also impairs fertility (Imsland et al. 2012). Such fitness-reducing mutations can be maintained in domestic birds when they are favoured by breeders. In populations of wild birds, they may similarly be maintained when they are favoured by mate choice or other social interactions. Furthermore, drift effects in small populations can also result in the fixation of (mildly) deleterious mutations. Subsequent evolution will then favour additional mutations that ameliorate the deleterious effect. This is exemplified by the Rose comb mutation in chickens, in which the original mutation caused reduced sperm motility and thus impaired fertility (Imsland et al. 2012). A secondary mutation in the same genomic region restored fertility (Imsland et al. 2012). Such a compensatory mutation is likely to be a pervasive force in evolution (Denver et al. 2010).

Once a new ornamental trait has established, subsequent mutations can cause further elaboration and diversification of the trait. Furthermore, sexual dimorphism may evolve through a variety of mechanisms, which may be easier for some traits than for others. Therefore, both selection and constraints are likely to play a role in the evolution of sexual dimorphism, and their relative importance may differ between traits.

While the cases reviewed in this paper are largely consistent with Lande's model in terms of sequence of evolutionary events, it is worth noting that some assumptions of this model are not supported. In particular, Lande (1980) assumed both traits and sexual dimorphism to be highly polygenic. This meant that the evolution of sexual dimorphism would have to be a slow process, as each gene involved in ornament development would have to evolve sexually dimorphic expression independently. Ornamental traits in domestic birds, however, show that ornaments can be caused by single mutations of large effect and thus appear more or less instantaneously. Likewise, sexual dimorphism may be gained by linking the expression of a key gene in the developmental pathway to an existing sexually dimorphic signal. Again, it would seem that sexual dimorphism may appear instantaneously, although we have no actual examples of this happening. Therefore, while the studies discussed here support the sequence of events leading to sexually dimorphic ornamentation proposed by Lande (1980), they do not support the postulated slow and gradual mode of ornament evolution.

Based on these considerations, I propose that sexually monomorphic ornaments in birds may include traits that (1) 
never evolved dimorphism because selection did not favour it; (2) are under positive selection for dimorphism, but are difficult to modulate; (3) could be modulated easily, but are selected for monomorphism; and (4) are a side-effect of selection on hormone levels, rather than on the ornament itself. The relative contribution of each of these processes to the diversity of sexually monomorphic ornaments in nature awaits further study. More generally, future studies on wild birds could be targeted using information from domestic birds, while further studies on domestic birds could address outstanding questions arising from patterns observed in wild birds. As first priorities, such studies should include scrutiny of the genes that cause novel ornaments in domestic birds in the genomes of wild birds and searching or selecting for domestic bird lineages in which the degree of sexual dimorphism has changed.

Acknowledgements I thank Michelle Hall and Kristal Cain for organising the Symposium on Ornamentation in Female Birds at the International Ornithological Congress 2018. Leif Andersson kindly alerted me to the Henny feathers phenotype in chickens. Shraddha Shitut prepared Fig. 2 and Alexander Brandt translated the abstract to German.

Open Access This article is distributed under the terms of the Creative Commons Attribution 4.0 International License (http://creativeco mmons.org/licenses/by/4.0/), which permits unrestricted use, distribution, and reproduction in any medium, provided you give appropriate credit to the original author(s) and the source, provide a link to the Creative Commons license, and indicate if changes were made.

\section{References}

Amundsen T (2000) Why are female birds ornamented? Trends Ecol Evol 15:149-155

Andersson M (1994) Sexual selection. Princeton University Press, Princeton

Boer EF, Van Hollebeke HF, Shapiro MD (2017) Genomic determinants of epidermal appendage patterning and structure in domestic birds. Dev Biol 429:409-419

Buchholz R (1997) Male dominance and variation in fleshy head ornamentation in wild turkeys. J Avian Biol 28:223-230

Clutton-Brock T (2009) Sexual selection in females. Anim Behav 77:3-11

Cooke TF, Fischer CR, Wu P, Jiang TX, Xie KT, Kuo J, Doctorov E, Zehnder A, Khosla C, Chuong CM et al (2017) Genetic mapping and biochemical basis of yellow feather pigmentation in Budgerigars. Cell 171:427-439.e21

Denver DR, Howe DK, Wilhelm LJ, Palmer CA, Anderson JL, Stein KC, Phillips PC, Estes S (2010) Selective sweeps and parallel mutation in the adaptive recovery from deleterious mutation in Caenorhabditis elegans. Genome Res 20:1663-1671

Dorshorst B, Harun-Or-Rashid M, Bagherpoor AJ, Rubin CJ, Ashwell C, Gourichon D, Tixier-Boichard M, Hallböök F, Andersson L (2015) A genomic duplication is associated with ectopic eomesodermin expression in the embryonic chicken comb and two duplex-comb phenotypes. PLoS Genet 11:e1004947

Feng C, Gao Y, Dorshorst B, Song C, Gu X, Li Q, Li J, Liu T, Rubin CJ, Zhao Y et al (2014) A cis-regulatory mutation of PDSS2 causes silky-feather in chickens. PLoS Genet 10:e1004576
Guernsey MW, Ritscher L, Miller MA, Smith DA, Schöneberg T, Shapiro MD (2013) A Val85Met mutation in melanocortin-1 receptor is associated with reductions in eumelanic pigmentation and cell surface expression in domestic rock pigeons (Columba livia). PLoS ONE 8:e74475

Guo Y, Gu X, Sheng Z, Wang Y, Luo C, Liu R, Qu H, Shu D, Wen J, Crooijmans RP, Carlborg O, Zhao Y, Hu X, Li N (2016) A complex structural variation on chromosome 27 leads to the ectopic expression of HOXB8 and the Muffs and Beard phenotype in chickens. PLoS Genet 12:e1006071

Headon D (2015) Morphological mutations: lessons from the cockscomb. PLoS Genet 11:e1004979

Imsland F, Feng C, Boije H, Bed'hom B, Fillon V, Dorshorst B, Rubin C-J, Liu R, Gao Y, Gu X et al (2012) The rose-comb mutation in chickens constitutes a structural rearrangement causing both altered comb morphology and defective sperm motility. PLoS Genet 8:e1002775

Kanzler B, Prin F, Thelu J, Dhouailly D (1997) CHOXC-8 and CHOXD-13 expression in embryonic chick skin and cutaneous appendage specification. Dev Dyn 210:274-287

Kimball RT, Ligon JD (1999) Evolution of avian plumage dichromatism from a proximate perspective. Am Nat 154:182-193

Kraaijeveld K (2014) Reversible trait loss: the genetic architecture of female ornaments. Annu Rev Ecol Evol Syst 45:159-177

Kraaijeveld K, Reumer BM (2008) Constraints and the evolution of mutual ornamentation. In: Weber EA, Krause LH (eds) Animal behavior: new research. Nova, Hauppauge, pp 193-213

Kraaijeveld K, Gregurke J, Hall C, Komdeur J, Mulder RA (2004) Mutual ornamentation, sexual selection, and social dominance in the Black Swan. Behav Ecol 15:380-389

Kraaijeveld K, Kraaijeveld-Smit FJL, Komdeur J (2007) The evolution of mutual ornamentation. Anim Behav 74:657-677

Lambeth LS, Morris KR, Wise TG, Cummins DM, O’Neil TE, Cao Y, Sinclair AH, Doran TJ, Smith CA (2016) Transgenic chickens overexpressing aromatase have high estrogen levels but maintain a predominantly male phenotype. Endocrinology 157:83-90

Lande R (1980) Sexual dimorphism, sexual selection, and adaptation in polygenic characters. Evolution 34:292-305

Leshin M (1985) 5-Azacytidine and sodium butyrate induce expression of aromatase in fibroblasts from chickens carrying the henny feathering trait but not from wild-type chickens. Proc Natl Acad Sci USA 82:3005-3009

Lorenzo AJ, Nguyen MT, Sozubir S, Henkemeyer M, Kropp B, Baker LA (2003) Dihydrotestosterone induction of EphB2 expression in the female genital tubercle mimics male pattern of expression during embryogenesis. J Urol 170:1618-1623

Lu XIN (2007) Male behaviors of socially monogamous Tibetan Eared-pheasants during the breeding season. Wilson J Ornithol 119:592-601

Lyon BE, Montgomerie R (2012) Sexual selection is a form of social selection. Philos Trans R Soc Lond B Biol Sci 367:2266-2273

Matsumine H, Herbst MA, Ou SHI, Wilson JD, McPhaul MJ (1991) Aromatase mRNA in the extragonadal tissues of chickens with the henny-feathering trait is derived from a distinctive promoter structure that contains a segment of a retroviral long terminal repeat. J Biol Chem 266:19900-19907

Mou C, Pitel F, Gourichon D, Vignoles F, Tzika A, Tato P, Yu L, Burt DW, Bed'hom B, Tixier-Boichard M, Painter KJ, Headon DJ (2011) Cryptic patterning of avian skin confers a developmental facility for loss of neck feathering. PLoS Biol 9:e1001028

Ng CS, Wu P, Foley J, Foley A, McDonald ML, Juan WT, Huang CJ, Lai YT, Lo WS, Chen CF, Lea SM, Zhang H, Widelitz RB, Patel PI, Li WH, Chuong CM (2012) The chicken frizzle feather is due to an $\alpha$-Keratin (KRT75) mutation that causes a defective rachis. PLoS Genet 8:e1002748 
Noorai RE, Freese NH, Wright LM, Chapman SC, Clark LA (2012) Genome-wide association mapping and identification of candidate genes for the rumpless and ear-tufted traits of the Araucana chicken. PLoS ONE 7:e40974

Owens IP, Short RV (1995) Hormonal basis of sexual dimorphism in birds: implications for new theories of sexual selection. Trends Ecol Evol 10:44-47

Pennell TM, Morrow EH (2013) Two sexes, one genome: the evolutionary dynamics of intralocus sexual conflict. Ecol Evol 3:1819-1834

Price TD (2002) Domesticated birds as a model for the genetics of speciation by sexual selection. Genetica 116:311-327

Price JJ, Eaton MD (2014) Reconstructing the evolution of sexual dichromatism: current color diversity does not reflect past rates of male and female change. Evolution 68:2026-2037

Schwochow Thalmann D, Ring H, Sundström E, Cao X, Larsson M, Kerje S, Höglund A, Fogelholm J, Wright D, Jemth P et al (2017) The evolution of Sex-linked barring alleles in chickens involves both regulatory and coding changes in CDKN2A. PLoS Genet 13:e1006665

Shapiro MD, Kronenberg Z, Li C, Domyan ET, Pan H, Campbell M, Tan H, Huff CD, Hu H, Vickrey AI et al (2013) Genomic diversity and evolution of the head crest in the rock pigeon. Science 339:1063-1067

Tobias JA, Montgomerie R, Lyon BE (2012) The evolution of female ornaments and weaponry: social selection, sexual selection and ecological competition. Philos Trans R Soc Lond B Biol Sci 367:2274-2293

Vickrey AI, Domyan ET, Horvath MP, Shapiro MD (2015) Convergent evolution of head crests in two domesticated columbids is associated with different missense mutations in EphB2. Mol Biol Evol 32:2657-2664

Wang Y, Gao Y, Imsland F, Gu X, Feng C, Liu R, Song C, TixierBoichard M, Gourichon D, Li Q et al (2012) The crest phenotype in chicken is associated with ectopic expression of hoxc 8 in cranial skin. PLoS ONE 7:e34012

West-Eberhard MJ (1979) Sexual selection, social competition, and evolution. Proc Am Philos Soc 123:222-234

Wiens JJ (2001) Widespread loss of sexually selected traits: how the peacock lost its spots. Trends Ecol Evol 16:517-523

Wright D, Boije H, Meadows JRS, Bed'hom B, Gourichon D, Vieaud A, Tixier-Boichard M, Rubin C-J, Imsland F, Hallböök F et al (2009) Copy number variation in intron 1 of SOX 5 causes the peacomb phenotype in chickens. PLoS Genet 5:e1000512

Publisher's Note Springer Nature remains neutral with regard to jurisdictional claims in published maps and institutional affiliations.

\section{Affiliations}

\section{Ken Kraaijeveld ${ }^{1}$ (D)}

Ken Kraaijeveld

ken@kenkraaijeveld.nl
1 Institute for Biodiversity and Ecosystem Dynamics, University of Amsterdam, Sciencepark 904, 1090 GE Amsterdam, The Netherlands 